\title{
UPAYA MENINGKATAN HASIL BELAJAR DALAM MENANGGAPI ISI LAPORAN MELALUI MODEL COOPERATIVE LEARNING PEMBELAJARAN KEPALA BERNOMOR STRUKTUR (NHT) PADA PESERTA DIDIK KELAS VIII F SEMESTER 1 SMP NEGERI 7 SUKOHARJO TAHUN PELAJARAN 2017/2018
}

\author{
Sri Wahyuni \\ SMP Negeri 7 Sukoharjo, Jawa Tengah \\ Email: sriwahyuni@gmail.com
}

\begin{abstract}
Abstrak: Penelitian ini bertujuan untuk meningkatkan hasil belajar Bahasa Indonesia materi kemampuan menanggapi isi laporan melalui model cooperative learning pembelajaran kepala bernomor struktur (NHT) pada siswa kelas VIII F SMP Negeri 7 Sukoharjo Semester I Tahun Pelajaran 2017/2018. Metode penelitian menggunakan Penelitian Tindakan Kelas yang dilaksanakan dalam dua siklus setiap siklus terdiri dua kali pertemuan, dengan empat tahap penelitian: perencanaan, pelaksanaan, pengamatan dan refleksi. Subjek penelitian ini adalah siswa-siswi kelas VIII F SMP Negeri 7 Sukoharjo semester I tahun ajaran 2017/2018. Dengan jumlah 24 siswa. Teknik pengumpulan data yang digunakan adalah observasi, wawancara, tes, dan dokumentasi. Analisis data yang digunakan dalam penelitian ini adalah analisis deskriptif kualitatif. Hasil penelitian ini adalah meningkatkan hasil belajar Bahasa Indonesia materi kemampuan menanggapi isi laporan. Hal ini dibuktikan dengan peningkatan hasil belajar siswa pada siklus I siswa yang berhasil mendapat nilai KKM, meningkat dari 13 siswa atau 54,16 menjadi 16 siswa atau $66,66 \%$ atau terdapat peningkatan sebesar $12,50 \%$ dibandingkan kondisi awal. Sedangkan pada siklus II meningkat menjadi 21 siswa yang mendapat nilai diatas KKM atau 87,50\% atau terdapat peningkatan sebesar 20,84\% dari sebelumnya. Berdasarkan hasil penelitian ini dapat disimpulkan bahwa dengan penerapan model cooperative learning pembelajaran kepala bernomor struktur (NHT) dapat meningkatkan hasil belajar Bahasa Indonesia materi kemampuan menanggapi isi laporan pada siswa kelas VIII F SMP Negeri 7 Sukoharjo Semester I Tahun Pelajaran 2017/2018.
\end{abstract}

Kata kunci: hasil belajar, Bahasa Indonesia, isi laporan, cooperative learning NHT

\begin{abstract}
This study aims to improve the learning outcomes of Bahasa Indonesia material the ability to respond to the contents of the report through the model of cooperative learning headed learning structure number (NHT) on students of class VIII F SMP Negeri 7 Sukoharjo Semester I Lesson 2017/2018. The research method using Classroom Action Research which is carried out in two cycles each cycle consists of two meetings, with four stages of research: planning, implementation, observation and reflection. The subject of this research is the students of class VIII F SMP Negeri 7 Sukoharjo semester I of academic year 2017/2018. With 24 students. Data collection techniques used are observation, interviews, tests, and documentation. Data analysis used in this research is descriptive qualitative analysis. The results of this study is to improve the learning achievement of Bahasa Indonesia material ability to respond to the contents
\end{abstract}


of the report. This is evidenced by the increase in student learning outcomes in the first cycle of students who managed to get KKM scores, increased from 13 students or 54.16 to 16 students or $66.66 \%$ or an increase of $12.50 \%$ compared to the initial conditions. While in the second cycle increased to 21 students who got a value above the KKM or $87.50 \%$ or an increase of $20.84 \%$ from the previous. Based on the result of this research, it can be concluded that with the implementation of cooperative learning model of headed learning structure numbered (NHT) can improve the learning result of Bahasa Indonesia material of ability to respond to report contents in grade VIII F SMP Negeri 7 Sukoharjo Semester I Lesson Year 2017/2018.

Keywords: learning outcomes, Bahasa Indonesia, report content, cooperative learning NHT

\section{PENDAHULUAN}

Bahasa Indonesia merupakan suatu bahasa nasional yang digunakan oleh rakyat Indonesia. Dimana bahasa menjadi suatu atau sebuah sarana komunikasi bagi bangsa Indonesia kita tercinta. Bahasa Indonesia inilah yang mempersatukan komunikasi dari berbagai suku yang ada di Indonesia. Bahasa yang sangat penting untuk dipelajari lebih mendalam bagi bangsa Indonesia, terutama bagi para generasi muda sekarang ini dimana mereka merupakan penerus bangsa ini ke depan agar tetap komitmen dalam mempertahankan bahasa nasional ini sampai kapanpun terutama melalui sektor pendidikan. Pendidikan menjadi motor penggerak bagi keberlangsungan sumber daya manusia yang handal suatu negara, karena pendidikan merupakan cara terbaik untuk meningkatkan kualitas sumber daya manusia suatu bangsa (Tho'in, 2017: 162). Sehingga pendidikan menjadi suatu aspek kehidupan yang sangat mendasar bagi pembangunan bangsa.

Penyelenggaraan pendidikan di sekolah melibatkan guru sebagai pendidik dan siswa sebagai peserta didik. Hal tersebut diwujudkan dengan adanya interaksi belajar mengajar atau proses pembelajaran. Proses pembelajaran yang dilakukan oleh banyak tenaga pendidik saat ini cenderung pada pencapaian target materi kurikulum atau lebih mementingkan pada penghafalan konsep bukan pada pemahaman. Hal ini dapat dilihat dari kegiatan pembelajaran di dalam kelas yang selalu didominasi oleh guru. Dalam penyampaian materi, biasanya guru menggunakanmodel ceramah, di mana siswa hanya duduk, mencatat, dan mendengarkan apa yang disampaikannya dan sedikit peluang bagi siswa untuk bertanya. Pembelajaran biasanya hanya disampaikan secara konvensional, dimana guru yang berperan aktif, sementara siswa cenderung pasif. Sikap siswa yang pasif dapat mengurangi keterlibatannya dalam mengikuti proses pembelajaran yang dapat mengakibatkan turunnya minat siswa dalam mengikuti proses pembelajaran.

Masalah lain yang muncul adalah rendahnya kemampuan sosial antar siswa. Rendahnya rasa sosial ini akan menimbulkan sifat individualisme pada diri siswa. Hal ini sangat tidak baik jika terus menerus ada di dalam diri siswa. Oleh karena itu guru harus berperan aktif untuk menumbuhkan rasa sosial di antara siswa. Karena dengan tingginya 
kemampuan sosial yang dimiliki, para siswa akan lebih mudah berbaur di dalam lingkungan hidupnya.

Dalam hal lain yang dapat dikatakan masalah adalah kurangnya rasa percaya diri dalam diri siswa untuk mengemukakan pendapat dan berbicara di depan umum. Banyak siswa yang lebih memilih untuk memendam pendapatnya selama proses pembelajaran. Sebagai pengajar, guru harus membantu siswa menggali kepercayaan diri mereka. Karena dengan adanya rasa percaya diri, siswa akan lebih yakin untuk berbicara di hadapan orang. Hasil belajar siswa sangat dipengaruhi oleh kualitas pembelajaran yang dilaksanakan di sekolah. Salah satu yang menentukan kualitas pembelajaran adalah penggunaan model pembelajaran yang tepat dengan materi yang diajarkan. Pada kenyataannya banyak sekolah yang kurang memperlihatkan penggunaan model pembelajaran dalam setiap penampilan mengajar.

Dengan demikian, suasana pembelajaran menjadi tidak kondusif sehingga siswa menjadi pasif. Kenyataan ini berlaku untuk semua mata pelajaran termasuk mata pelajaran Bahasa Indonesia. Bahasa indonesia merupakan bahasa persatuan yang menjadi identitas bangsa Indonesia. Untuk menjaga kelestarian dan kemurnian bahasa Indonesia maka diperlukan berbagai upaya. Dapat digunakan sebagai pedoman dalam kegiatan berkomunkasi menggunakan bahasa Indonesia dengan benar, baik berkomunikasi secara langsung maupun tidak langsung. Sedangkan upaya lain yang dapat digunakan untuk melestarikan bahasa Indonesia adalah dengan menanamkan bahasa Indonesia sejak dini.

Penanaman bahasa Indonesia sejak dini adalah memberikan pelatihan dan pendidikan tentang bahasa Indonesia sejak masih kecil. Pelaksanaan pendidikan tentang bahasa Indonesia pada anak dapat dilakukan melalui pendidikan informal, pendidikan formal, dan pendidikan non formal. Pendidikan informal dilakukan dirumah. Pendidikan ini dilakukan saat anak berada dirumah bersama dengan keluarganya. Sedangkan pendidikan formal, gurulah yang berperan penting dalam menanamkan pengetahuan akan bahasa Indonesia yang baik. Sedangkan pendidikan nonformal dilakukan diluar jam sekolah, dapat melalui kursus pelatihan-pelatihan dan lain-lain.

Upaya peningkatan prestasi belajar siswa tidak terlepas dari berbagai faktor yang mempengaruhinya. Dalam hal ini, diperlukan guru kreatif yang dapat membuat pembelajaran menjadi lebih menarik dan disukai oleh peserta didik. Suasana kelas perlu direncanakan dan dibangun sedemikian rupa dengan menggunakan model pembelajaran yang tepat agar siswa dapat memperoleh kesempatan untuk berinteraksi satu sama lain sehingga pada gilirannya dapat diperoleh prestasi belajar yang optimal. Untuk itu perlu disadari oleh guru bahwa dalam melaksanakan pembelajaran perlu pula diupayakan pembelajaran yang bersifat membangun dan memberikan pengalaman terhadap materimateri yang diberikan.

Keterbatasan waktu yang tersedia menyebabkan guru mengejar target pencapaian kurikulum memilih jalan yang termudah untuk menginformasikan fakta dan konsep, yaitu melalui model ceramah kemudian latihan soal dan siswa memperhatikan penjelasan guru tanpa melakukan aktivitas sehingga siswa pasif. Guru dalam mengajarkan Bahasa Indonesia khususnya sub pokok bahasan memahami kemampuan menanggapi isi laporan 
kepada siswa kurang melibatkan siswa secara aktif dalam interaksi belajar mengajar sehingga siswa kurang termotivasi dalam belajar. Guru juga kurang melibatkan lingkungan sebagai media sehingga siswa kurang mengenal lingkungan dan tidak dapat memperoleh pemahaman yang berarti. Disaat proses belajar mengajar berlangsung, guru kurang menggunakan model pembelajaran yang bervariasi sehingga hal tersebut dapat menyebabkan siswa jenuh dan kurang aktif. Guru beranggapan sulit menerapkan model pembelajaran misalnya untuk materi kemampuan menanggapi isi laporan.

Penggunaan berbagai macam model pembelajaran dapat memakan waktu yang lebih lama sementara waktu mengajarnya terbatas. Guru juga jarang sekali menggunakan pendekatan pembelajaran ketika sedang mengajarkan materi Bahasa Indonesia. Terkait belum optimalnya proses pembelajaran Bahasa Indonesia di kelas VIII F Semester I SMP Negeri 7 Sukoharjo maka peneliti berupaya untuk menerapkan model pembelajaran cooperative learning kepala bernomor struktur (NHT) sebagai salah satu alternatif pembelajaran bermakna yang bermuara pada pembelajaran yang aktif, kreatif, efektif dan menyenangkan.

Kepala bernomor struktur merupakan model pembelajaran hasil modifikasi dari Numbered Heads Together (NHT). Model pembelajaran ini masih menggunakan nomor di kepala sebagai identitas utamanya. Bedanya adalah nomor-nomor di kepala pada model ini dibuat secara berulang dan berurutan. Misalnya dalam satu kelas terdapat lima kelompok dan masing-masing kelompok terdiri dari lima orang. Maka nomor-nomornya adalah 1-5 untuk setiap kelompok. Ciri lainnya dari model pembelajaran ini adalah setiap nomor yang sama memiliki tugas-tugas yang berbeda. Misalnya nomor satu bertugas mencatat, nomor dua dan tiga bertugas berdiskusi, dan nomor empat dan lima bertugas membawakan presentasi. Pembagian tugas ini berlaku sama untuk semua kelompok.

\section{KAJIAN TEORI}

\section{Teori Hasil Belajar Siswa}

Menurut R. Gagne seperti yang dikutip oleh Slameto (2000:78) memberikan dua definisi belajar, yaitu belajar adalah suatu proses untuk memperoleh motivasi dalam pengetahuan, keterampilan, kebiasaan, dan tingkah laku. Belajar adalah penguasaan pengetahuan atau keterampilan yang diperoleh dari instruksi. Menurut Skinner yang dikutip oleh Dimyati dan Mudjiono (2006:93) bahwa belajar merupakan hubungan antara stimulus dan respon yang tercipta melalui proses tingkah laku. M. Sobry Sutikno (2010:35) mengemukakan belajar merupakan suatu proses usaha yang dilakukan oleh seseorang untuk memperoleh suatu perubahan yang baru sebagai hasil pengalamannya sendiri dalam interaksi dengan lingkungannya.

Berdasarkan beberapa pengertian di atas maka dapat penulis simpulkan bahwa belajar adalah perubahan serta peningkatan kualitas dan kuantitas tingkah laku seseorang di berbagai bidang yang terjadi akibat interaksi terus menerus dengan lingkungannya.

Hasil belajar siswa menurut W. Winkel (2004:82) adalah keberhasilan yang dicapai oleh siswa, yakni prestasi belajar siswa di sekolah yang mewujudkan dalam bentuk angka. Hasil belajar adalah pola-pola perbuatan, nilai-nilai, pengertian-pengertian, sikap- 
sikap, apresiasi dan keterampilan-keterampilan (Suprijono, 2011:5). Hasil belajar adalah hasil yang dicapai dalam bentuk angka atau skor setelah tes hasil belajar pada setiap akhir pembelajaran (Dimyati dan Mujiono, 2006:24).

Definisi di atas dapat disimpulkan bahwa hasil belajar adalah prestasi belajar yang dicapai siswa dalam proses kegiatan belajar mengajar dengan membawa suatu perubahan dan pembentukan tingkah laku seseorang. Untuk menyatakan bahwa suatu proses belajar dapat dikatakan berhasil, setiap guru memiliki pandangan masing-masing sejalan dengan filsafatnya. Namun untuk menyamakan persepsi sebaiknya kita berpedoman pada kurikulum yang berlaku saat ini yang telah disempurnakan, antara lain bahwa suatu proses belajar mengajar tentang suatu bahan pembelajaran dinyatakan berhasil apabila tujuan pembelajaran khususnya dapat dicapai.

Dalam rangka mengetahui tercapai tidaknya tujuan pembelajaran khusus, guru perlu mengadakan tes formatif pada setiap menyajikan suatu bahasan kepada siswa. Penilaian formatif ini untuk mengetahui sejauh mana siswa telah menguasai tujuan pembelajaran khusus yang ingin dicapai. Fungsi penelitian ini adalah untuk memberikan umpan balik pada guru dalam rangka memperbaiki proses belajar mengajar dan melaksanakan program remedial bagi siswa yang belum berhasil. Karena itulah, suatu proses belajar mengajar dinyatakan berhasil apabila hasilnya memenuhi tujuan pembelajaran khusus dari bahan tersebut.

Hasil belajar yang dicapai oleh siswa di sekolah merupakan salah satu ukuran terhadap penguasaan materi pelajaran yang disampaikan. Peran guru dalam menyampaikan materi pelajaran dapat mempengaruhi hasil belajar siswa. Faktor-faktor yang mempengaruhi hasil belajar siswa penting sekali untuk diketahui, artinya dalam rangka membantu siswa mencapai hasil belajar yang seoptimal mungkin. Hasil belajar akan semakin maksimal jika semua unsur masyarakat menyadari pentingnya pendidikan, karena pendidikan cara perbaik memperbarui kualitas bangsa (Tho'in, 2017).

Hasil belajar yang dicapai siswa dipengaruhi oleh dua faktor baik yang bersifat mendorong atau menghambat, demikian pula dalam belajar. Faktor yang mempengaruhi prestasi atau hasil belajar siswa yakni faktor dari dalam diri siswa (interen) dan faktor yang datang dari luar (eksteren). Ahmadi (1998:72) mengemukakan untuk mencapai prestasi belajar siswa sebagaimana yang diharapkan, maka perlu diperhatikan beberapa faktor yang mempengaruhinya antara lain faktor yang terdapat dalam diri siswa (faktor intern) dan faktor yang berasal dari luar diri siswa (faktor ekstern).

\section{Menanggapi Isi Laporan}

Suatu bentuk penyampaian berita, keterangan, pemberitahuan ataupun pertanggungjawaban baik secara lisan maupun secara tertulis dari bawahan kepada atasan sesuai dengan hubungan wewenang dan tanggung jawab yang ada diantara mereka. Secara umum laporan adalal alat penyampaian informasi dari 1 pihak ke pihak lain. Secara administrasi laporan adalah alat penyampaian informasi dari 1 pegawai ke paegawai lain dalam lingkup administrasi. 
Fungsi laporan diantaranya adalah sebagai berikut: Pertama, pertanggungjawaban bagi orang yang diberi tugas. Kedua, landasan pimpinan dalam mengambil kebijakan/keputusan. Ketiga, alat untuk melakukan pengawasan. Keempat, dokumen sebagai bahan studi dan pengalaman bagi orang lain. Macam-macam laporan menurut bentuknya: pertama, laporan berbentuk formulir. Kedua. laporan berbentuk surat. Ketiga, laporan berbentuk memorandum (memo). Keempat, laporan berbentuk naskah. Kelima, laporan berbentuk buku

Dasar-dasar Membuat Laporan antara lain sebagai berikut:

a. Clear. Kejelasan suatu laporan diperlukan baik kejelasan dalam pemakaian bahasa, istilah, maupun kata-kata harus yang mudah dicerna, dipahami dan dimengerti bagi si pembaca.

b. Mengenai sasaran permasalahannya. Caranya dengan jalan menghindarkan pemakaian kata-kata yang membingungkan atau tidak muluk-muluk, demikian juga hal dalam penyusunan kata-kata maupun kalimat harus jelasm singkat jangan sampai melantur kemana-mana dan bertele-tele yang membuat si pembaca laporan semakin bingung dan tidak mengerti.

c. Lengkap (complete). Kelengkapan tersebut menyangkut: Permasalahan yang dibahas harus sudah terselesaikan semua sehingga tidak menimbulkan tanda tanya. Pembahasan urutan permasalahan harus sesuai dengan prioritas penting tidaknya permasalahan diselesaikan

d. Tepat waktu dan cermat. Tepat waktu sangat diperlukan dalam penyampaian laporan kepada pihak-pihak yang membutuhkan karena pihak yang membutuhkan laporan untuk menghadapi masalah-masalah yang bersifat mendadak membutuhkan pembuatan laporan yang bisa diusahakan secepat-cepatnya dibuat dan disampaikan.

e. Tetap (consistent). Laporan yang didukung data-data yang bersifat tetap dalam arti selalu akurat dan tidak berubah-ubah sesuai dengan perubahan waktu dan keadaan akan membuat suatu laporan lebih dapat dipercaya dan diterima.

f. Objective dan Factual. Pembuatan laporan harus berdasarkan fakta-fakta yang bisa dibuktikan kebenarannya maupun dibuat secara obyektif.

g. Harus ada proses timbal balik. Laporan yang baik harus bisa dipahami dan dimengerti sehingga menimbulkan gairah dan minat si pembaca. Jika si pembaca memberikan respon berarti menunjukkan adanya proses timbal balik yang bisa memanfaatkan secara pemberi laporan maupun si pembaca laporan

\section{Model Cooperative Learning Tipe NHT}

Numbered Heads Together adalah model pembelajaran dengan cara setiap siswa diberi nomor dan dibuat suatu kelompok, kemudian secara acak guru memanggil nomor dari siswa. Slavin (2005: 256) memaparkan NHT pada dasarnya adalah sebuah group discussion, pembelokannya yaitu hanya pada satu siswa yang akan menjadi wakil kelompok tersebut. Tetapi sebelumnya tidak diberi tahu siapa yang menjadi wakil kelompok tersebut. Penerapan model NHT memastikan keterlibatan total dari semua siswa. Menurut Kagan dalam Ibrahim (2000: 28) model NHT adalah bagian dari model 
pembelajaran kooperatif struktural, yang menekankan pada struktur-struktur khusus yang dirancang untuk mempengaruhi pola interaksi siswa dan memiliki tujuan khusus untuk meningkatkan penguasaan akademik siswa dengan melibatkan para siswa menelaah bahan yang tercakup dalam suatu pelajaran dan pemahaman siswa terhadap isi pelajaran tersebut. Menurut Trianto (2010: 82) model NHT adalah jenis pembelajaran kooperatif yang dirancang untuk mempengaruhi pola interaksi siswa dan sebagai alternatif terhadap struktur kelas tradisional, yang lebih melibatkan siswa dalam menelaah materi yang tercakup dalam suatu pelajaran tersebut.

Berdasarkan uraian di atas, maka penulis menyimpulkan bahwa model cooperative learning tipe NHT adalah model kooperatif yang dirancang untuk mempengaruhi pola pikir siswa dengan tujuan meningkatkan aktivitas dan akademik siswa untuk memecahkan masalah dalam berdiskusi kelompok dan setiap anggota kelompok memiliki nomor yang berbeda. Kepala bernomor struktur merupakan model pembelajaran hasil modifikasi dari Numbered Heads Together (NHT). Model pembelajaran ini masih menggunakan nomor di kepala sebagai identitas utamanya. Bedanya adalah nomornomor di kepala pada model ini dibuat secara berulang dan berurutan. Misalnya dalam satu kelas terdapat lima kelompok dan masing-masing kelompok terdiri dari lima orang. Maka nomor-nomornya adalah 1-5 untuk setiap kelompok. Ciri lainnya dari model pembelajaran ini adalah setiap nomor yang sama memiliki tugas-tugas yang berbeda. Misalnya nomor satu bertugas mencatat, nomor dua dan tiga bertugas berdiskusi, dan nomor empat dan lima bertugas membawakan presentasi. Pembagian tugas ini berlaku sama untuk semua kelompok.

Dengan demikian melalui penyelenggaraan model NHT dalam proses belajar mengajar dapat menumbuhkan tanggung jawab siswa sehingga terlibat langsung secara aktif dalam memahami suatu persoalan dan menyelesaikannya secara kelompok.

Pada kegiatan ini ini keterlibatan guru dalam belajar mengajar semakin berkurang. dalam arti guru tidak lagi menjadi pusat kegiatan kelas. Guru berperan sebagai fasilitator yang mengarahkan dan memotivasi siswa untuk belajar mandiri serta menumbuhkan rasa tanggung jawab serta siswa akan merasa senang berdiskusi tentang materi pelajaran dalam kelompoknya.

Suprijono (2009: 92) memaparkan langkah-langkah pembelajaran menggunakan numbered heads together yakni: 1) Numbering, yaitu guru membagi kelas menjadi kelompok-kelompok kecil. 2) Guru mengajukan beberapa pertanyaan yang harus dijawab oleh tiap-tiap kelompok. 3) Kelompok berdiskusi menemukan jawaban. Pada kesempatan ini tiap-tiap kelompok berdiskusi memikirkan jawaban atas pertanyaan dari guru. Menyatukan kepalanya "heads together". 4) Guru memanggil peserta didik yang memiliki nomor yang sama tiap-tiap kelompok. Mereka diberi kesempatan memberi jawaban atas pertanyaan yang telah diterimanya dari guru. Berdasarkan jawaban itu guru dapat mengembangkan diskusi lebih mendalam, sehingga peserta didik dapat menemukan jawaban pertanyaan itu sebagai pengetahuan yang utuh.

Hal senada juga diungkapkan oleh Hamdani (2011: 90) yang mengungkapkan langkah-langkah model numbered heads together yaitu: 1) Siswa dibagi menjadi 
beberapa kelompok dan setiap siswa dalam setiap kelompok mendapat nomor. 2) Guru memberikan tugas dan tiap-tiap kelompok disuruh untuk mengerjakannya. 3) Kelompok mendiskusikan jawaban yang benar dan memastikan bahwa setiap anggota kelompok dapat mengerjakannya. 4) Siswa lain diminta untuk memberi tanggapan, kemudian guru menunjuk nomor lain.

Berdasarkan uraian di atas, langkah-langkah dalam pembelajaran cooperative learning tipe NHT yang melandasi penelitian ini adalah teori Trianto. Teori ini menekankan langkah-langkah NHT diawali dengan pembentukan kelompok, masingmasing anggota kelompok diberi nomor yang berbeda-beda. Selanjutnya guru memberikan tugas atau pertanyaan yang harus dipecahkan oleh peserta didik, siswa mulai berfikir bersama untuk mengerjakan soal yang diberikan guru. Dalam hal ini guru membimbing siswa dalam mengerjakan soal tersebut. Setelah siswa bekerja sama di dalam kelompok, langkah selanjutnya guru memanggil salah satu nomor masing-masing kelompok untuk mempersentasikan hasil kerja kelompok mereka.

\section{METODE}

Metode penelitian menggunakan penelitian tindakan kelas (PTK) yang dilaksanakan dalam dua siklus setiap siklus terdiri dua kali pertemuan, dengan empat tahap penelitian: perencanaan, pelaksanaan, pengamatan dan refleksi. Subjek penelitian ini adalah siswa-siswi kelas VIII F SMP Negeri 7 Sukoharjo tahun ajaran 2017/2018. Dengan jumlah 24 siswa. Teknik pengumpulan data yang digunakan adalah observasi, wawancara, tes, dan dokumentasi. Analisis data yang digunakan dalam penelitian ini adalah analisis deskriptif kualitatif.

\section{PEMBAHASAN}

Setelah peneliti melaksanakn tindakan penelitian melalui penerapan metode Cooperative Learning NHT, secara empiris diperoleh data peningkatan prestasi belajar Bahasa Indonesia materi kemampuan menanggapi isi laporan siswa kelas VIII F SMP Negeri 7 Sukoharjo Kecamatan Sukoharjo, Kabupaten Sukoharjo Semester I Tahun Pelajaran 2017/2018 dari kondisi awal, siklus I dan siklus II sebagai berikut.

Tabel 1. Peningkatan Prestasi Belajar Siswa

\begin{tabular}{|l|c|c|c|}
\hline \multicolumn{1}{|c|}{ Uraian } & Kondisi awal & Siklus I & Siklus II \\
\hline Tindakan & Belum menerapkan & $\begin{array}{c}\text { Sudah menerapkan } \\
\text { model NHT }\end{array}$ & $\begin{array}{c}\text { Sudah menerapkan } \\
\text { model NHT }\end{array}$ \\
\hline Nilai terendah & 60 & 60 & 70 \\
Nilai tertinggi & 80 & 90 & 90 \\
Nilai rata-rata & 70 & 75 & 85 \\
KKM & 75 & 75 & 75 \\
Ketuntasan & 13 siswa $(54,16 \%)$ & 16 siswa $(66,66 \%)$ & 21 siswa $(87,50 \%)$ \\
\hline
\end{tabular}

Melalui penerapan model Cooperative Learning NHT dapat meningkatkan prestasi belajar Bahasa Indonesia materi kemampuan menanggapi isi laporan. Pada kondisi awal peneliti belum menerapkan model Cooperative Learning NHT. Nilai rata-rata siswa kelas 
VIII F adalah 70, masih di bawah nilai KKM yang ditetapkan yaitu 75. Nilai tertinggi siswa 80, nilai terendah 60 dan jumlah siswa kelas VIII $F$ yang mencapai nilai KKM hanya 13 siswa $(54,16 \%)$ dari total 24 siswa kelas VIII F SMP Negeri 7 Sukoharjo.

Pada siklus I guru peneliti sudah menerapkan model Cooperative Learning NHT dalam pembelajaran Bahasa Indonesia materi kemampuan menanggapi isi laporan. Nilai rata-rata prestasi belajar Bahasa Indonesia materi kemampuan menanggapi isi laporan siswa kelas VIII F SMP Negeri 7 Sukoharjo adalah 75, nilai tertinggi 90 dan nilai terendah adalah 60. Sedangkan jumlah siswa yang mencapai nilai KKM sebanyak 16 siswa $(66,66 \%)$ dari total 24 siswa kelas VIII F SMP Negeri 7 Sukoharjo.

Pada siklus II, nilai rata-rata prestasi belajar Bahasa Indonesia materi kemampuan menanggapi isi laporan siswa kelas VIII F SMP Negeri 7 Sukoharjo adalah 85, nilai tertinggi 90 dan nilai terendah 70. Jumlah siswa yang mencapai nilai KKM sebanyak 21 siswa $(87,50 \%)$ dari total 24 siswa kelas VIII F SMP Negeri 7 Sukoharjo.

Jadi, melalui penerapan metode Cooperative Learning NHT dapat meningkatkan prestasi belajar Bahasa Indonesia materi kemampuan menanggapi isi laporan dari kondisi awal nilai rata-rata 70 dengan ketuntasan $54,16 \%$ ke kondisi akhir pada siklus II nilai rata-rata 85 dengan ketuntasan 87,50\% pada siswa kelas VIII F SMP Negeri 7 Sukoharjo semester I Tahun Pelajaran 2017/2018.

Hasil tindakan secara empirik yaitu: melalui penerapan metode Cooperative Learning NHT dapat meningkatkan prestasi belajar Bahasa Indonesia materi kemampuan menanggapi isi laporan dari kondisi awal nilai rata-rata 70 dengan ketuntasan 54,16\% ke kondisi akhir pada siklus II nilai rata-rata 85 dengan ketuntasan $87,50 \%$ pada siswa kelas VIII F SMP Negeri 7 Sukoharjo Semester I Tahun Pelajaran 2017/2018.

\section{SIMPULAN}

Hipotesis menyatakan diduga melalui penerapan metode Cooperative Learning NHT dapat meningkatkan prestasi belajar Bahasa Indonesia materi kemampuan menanggapi isi laporan pada siswa kelas VIII F SMP Negeri 7 Sukoharjo semester I Tahun Pelajaran 2017/2018. Dari data empirik menyatakan melalui penerapan metode Cooperative Learning NHT dapat meningkatkan prestasi belajar Bahasa Indonesia materi kemampuan menanggapi isi laporan dari kondisi awal nilai rata-rata 70 dengan ketuntasan 54,16\% ke kondisi akhir pada siklus II nilai rata-rata 85 dengan ketuntasan 87,50\% pada siswa kelas VIII F SMP Negeri 7 Sukoharjo Semester I Tahun Pelajaran 2017/2018. Sehingga dapat disimpulkan bahwa melalui penerapan metode Cooperative Learning NHT dapat meningkatkan prestasi belajar Bahasa Indonesia materi kemampuan menanggapi isi laporan pada siswa kelas VIII F SMP Negeri 7 Sukoharjo semester I Tahun Pelajaran 2017/2018.

\section{DAFTAR PUSTAKA}

Ahmadi, Abu. (1998). Psikologo Pendidikan. Jakarta : Rineka Cipta

Agus Suprijono. (2009). Cooperative Learning. Surabaya: Pustaka Pelajar. 
Sri Wahyuni / Edunomika Vol. 02 No. 01 (Pebruari 2018)

Dimyati dan Mudjiono. (2006). Belajar dan Pembelajaran. Jakarta: Rineka Cipta

Hamdani. (2011). Strategi Belajar Mengajar. Bandung : Pustaka Setia.

Heriawan, Adang dkk. (2012). Metodologi Pembelajaran Kajian Teoritis Praktis

Ibrahim. (2000). Pembelajaran Kooperatif. University Press. Surabaya.

Isjoni. 2010. Cooperative Learning Efektifitas Pembelajaran Kelompok. Bandung: Alfabeta

Kamus Besar Bahasa Indonesia. 2008. Pengertian Model.

M. Sobry Sutikno. 2010. Strategi Belajar Mengajar Melalui Penanaman Konsep Umum \& Konsep Islami. Refika Aditama: Bandung.

Nasution. 1995. Metode Research. Jakarta : PT. Bumi Aksara

Ngalim Purwanto. 1986. Psikologi Pendidikan. Bandung: PT Remaja Rosdakarya.

Slameto. (2000. Belajar dan Faktor-faktor yang mempengaruhinya. Rineka Cipta,Jakarta

Slavin, Robert E. (2005). Cooperative Learning: theory, research and practice (N. Yusron. Terjemahan). London: Allymand Bacon. Buku asli diterbitkan tahun 2005.

Tho'in, M. (2017). Pembiayaan Pendidikan Melalui Sektor Zakat. Al-Amwal: Jurnal Ekonomi dan Perbankan Syari'ah, 9(2).

Trianto. (2010). Mendesain Model Pembelajaran Inovatif-Progresif. Kencana. Jakarta

Winkel, W. S. (2004). Psikologi Pendidikan dan Evaluasi Belajar. Jakarta: PT. Gramedia Pustaka Utama. 